\title{
A life Cycle Cost Analysis and Environmental Assessment on the Photovoltaic System in Buildings: Two Case Studies in Iran
}

\author{
Hashem Amini Toosi, Zahra Balador, Morten Gjerde, and Ali Vakili-Ardebili
}

\begin{abstract}
The most important and abundant renewable energy in the world is solar energy which is going to be used increasingly. Life cycle assessment approach help us to analyze new and renewable technologies and quantify the impacts on the environment. The results of the studies show that $80 \%$ of the embodied energy is related to the manufacturing processes in producing the photovoltaic (PV) panels. Energy efficiency, location of the production phase, installation, building integration facilities and climate affect the performance of $\mathbf{P V}$ technology through its life cycle. In this paper we used a multi-dimensional assessment model including environmental impact assessment and cost analysis for a building integrated PV (BIPV) system. This BIPV system which can provide the whole required electricity for a single family house in two cities of Iran with different climatic conditions (Tehran and BandarAbbas) has been evaluated. The results in life cycle cost analysis on PV system showed that the payback period time is highly dependent on the maintenance costs of PV system especially while current energy generating plants provide low cost energy which are based on the fossil fuel resources in Iran. According to the calculations the payback period time of PV system is longer than technical life span of them by considering current electricity tariffs and initial costs; therefore, more governmental investment and subsidies are needed. Besides the environmental assessment of PV system, a comparison by fossil fuel based systems has been carried out in terms of environmental impact categories.
\end{abstract}

Index Terms-About life cycle assessment, life cycle cost analysis, environmental impacts, payback period, photovoltaic.

\section{INTRODUCTION}

The most important and abundant renewable energy in the world is solar energy which is going to be used increasingly [1], [2]. Based on numerous studies PV technology is supposed to be sustainable since it generates electricity from endless solar energy opposed to fossil-fuel based resources [3], [4]. It seems that PV panels convert solar energy to electricity without any energy consumption, but we should consider the production phase which is a high energy consuming process [5], [6], however, new technologies introduce new ways to produce PV panels with less environmental impacts in different stages of manufacturing and extracting materials. Studies show a significant increase in the production of PV panels and an enormous decrease in

Manuscript received May 5, 2017; revised August 12, 2017.

Hashem Amini Toosi and Ali Vakili-Ardebili are with School of Architecture, College of Fine Arts, University of Tehran, Tehran, Iran (e-mail: Hashemamini@alumni.ut.ac.ir, avakiliardebili@ut.ac.ir).

Zahra Balador and Morten Gjerde are with School of Architecture and Design, Victoria University of Wellington, Wellington, New Zealand (e-mail: Zahra.balador@vuw.ac.nz, morten.gjerde@vuw.ac.nz). the costs of the production [7]. High costs of a novel technology limit the use of the product. Lower weight, high manufacturing speed, lower thermal investment, and less demanding and less complex manufacturing equipment are the factors which lead to a cost efficient photovoltaic production [8]. Life cycle thinking help us to assess new and renewable technologies and evaluate the impacts on the environment. The results of the studies show that $80 \%$ of the embodied energy is related to the manufacturing process in order to produce the PV panels. Energy efficiency, location of the production, installation, building integration facilities and climate affect the performance of PV technology through its life cycle [8].

Researchers have shown that because the lifetime of the PV panels exceed 20 years, the energy payback time of modules should be lower than the lifetime. Besides $\mathrm{CO}_{2}$ emissions of PV is lower than fossil fuel plants; therefore, PV technology can help the mitigation of global warming [9]. Different studies have proved that multi crystal PV modules have an energy payback time (EPBT) about 3-4 years in Rome [10]. EPBT of roof-mounted BIPV system in Hong Kong in proportion to its lifespan is short and about 7.3 years, but with rapid development of technology the results can change in line with the technology, also can vary according to the changes in the location and the orientation of the system. Estimates show that the green-house gas (GHG) payback time is 5.2 years [11]. R. Wilson studied two buildings with natural ventilation and air condition system, and calculated EPBT of them which were 7.4 and 12.1 respectively [12]. According to some researches, by optimizing the construction phase and scale, the environmental impacts can be reduced to $30 \%$ [12]. In 2004 and in 2003, Australian Coal Industry Association Research Program and European Community respectively demonstrated through some studies that photovoltaic is not only environmental friendly, but also has high environmental impacts; however, the EPBT for different types of multi-crystal photovoltaic panels was calculated and is about 2-7.5 years, also they studied on the GHG emissions of these types which were in the range of 12 to $110 \mathrm{~g} \mathrm{CO}_{2}$ eq./kWh [13]. Some studies in 2011 indicated that multi-Si has EPBT of 1.5-7.5 and GHG emissions about $12-170 \mathrm{~g} \mathrm{CO}_{2}$ eq./kWh. More recent studies in 2013 showed that new technologies in the production process will lead to reduce the EPBT to less than a half [14]. Mezher and Chedid developed a method for optimizing a process which is minimization of costs, maximization of system efficiency, minimization of use of conventional fossil fuel, maximizing use of locally available material, maximizing employment, and minimizing $\mathrm{CO}_{2}, \mathrm{SO}_{2}$ emissions [15]. Closed-loop 
recycling will reduce the environmental impacts of any product, but further studies are needed on the materials after disposal, re-using or recycling of PV panel materials [16].

Since it is not an easy task to compare different studies from various part of the world due to the different conditions and issues, we should evaluate the factors in the location of the study. That is, if the location of the production and the use stage is different according to the distance and other factors, estimation of the EPBT can be a challenge.

\section{MATERIALS AND METHODS}

In most reliable LCA methods, a life cycle assessment framework is divided into four steps: (1) Goal and Scope Definition, (2), Inventory Analysis, (3) Impact Assessment, and (4) Interpretation. LCA study is a comprehensive approach towards investigating environmental problems. The most advantageous aspects of LCA study are calculating energy payback time, quantifying and identifying major contributors to the environmental problems and energy consumption [17].

The goal of the present study is to quantify the energy use and global warming potential of the PV system in comparison with different electricity supplying systems. Besides, calculating initial investment, energy payback time based on the economical methods which are explained in detail in the next section. The scope of the current study is reporting the environmental impacts and the economical assessment of BIPV. Functional Unit of this assessment is the whole PV modules required to support the required electricity of a single average (four-people) residential unit. Life span of photovoltaic panels is considered 25 years, which is the average of different brands produced currently. System Boundary defined in this research included four life cycle stages of a product which are extraction and production, installation, operation and disposal. The second step is gathering inventories data from Ecoinvent 3.0. Gathering inventories of all the relevant materials and processes in the life cycle has been done. Given products have some emissions which are translated into impacts in the third step and the next step is allocated to the discussion. The inventory data of environmental impacts are gathered from Ecoinvent, which are collected from companies involved in the production of photovoltaics which in this study is multi-Sci, flat roof installation, $3 \mathrm{kWp}$ produced in Taiwan.

\section{A. Life Cycle Environmental Impact Assessment Methodology}

The environmental impact assessment index was calculated by (1): [18]

$$
I A \operatorname{Index}_{j k}=\frac{I A_{j k} * I V w t_{k}}{\text { Norm }_{k}} * 100
$$

where:

$I A_{j k}=I A_{j k}$ was calculated by using LCA database such as Ecoinvent 3.

$I V w t_{k}=$ The weighting factor for $\mathrm{k}_{\mathrm{th}}$ environmental impact

Norm $_{\mathrm{k}}=$ The normalization factor for $\mathrm{k}_{\mathrm{th}}$ environmental impact (based on the BEES method)

\section{B. Life Cycle Cost Analysis Methodology}

With a belief in the sustainability, we should consider all aspects of sustainability like economical parameters in the lifetime of a product. For evaluating economic performance of PV panels in their lifetime, life cycle cost analysis (LCCA) is needed in order to balance the initial investment, maintenance and operation costs and benefits [19]. Embedded energy, solar irradiation and system efficiency are all affect the payback time. Insolation has the greatest effect on the reduction of the payback time. Besides, future improvement in the production technology will also reduce this payback time period [20]. Generally, LCCA study encompasses inflation, discount and time value of money. In this case, LCCA steps involve defining objectives, determining the criteria, gathering cost information and calculating [19]. Payback period calculates how fast a product will recover its costs and investment. Dynamic payback period which encompasses discount rate, is more accurate and is calculated as follows [21]:

$$
\text { Payback Period }=A+B / C
$$

where:

$A$ : the last period with a negative cumulative cash flow;

$B$ : the absolute value of cumulative cash flow at the end of the period $A$;

$C$ : the total cash flow during the period after $A$.

In this study EnergyPlus 8.3 is used to evaluate energy performance and PV modules are modeled with Ecotect. The study is conducted in two different cities (Tehran and Bandar Abbas) with different climate conditions and at the end the results have been compared with each other. The first input data is climate condition and location, the second input set is dimensions of the PV panels which is imported from Ecotect and the third input data is the specification of the system. We have gathered the average electricity consumption data for residential buildings from Iran's Ministry of Energy in Tehran and Bandar Abbas which are $300 \mathrm{KWh}$ and $800 \mathrm{KWh}$ per month respectively [22]. The number of required PV modules are calculated based on the average required electricity and the specifications of the modules are chosen from the Energy Plus library. Characteristics of the module and data resources are shown in the Table I.

\begin{tabular}{ll}
\multicolumn{2}{c}{ TABLE I: SPECIFICATION OF PV MODULES } \\
\hline \hline Item & Description \\
\hline Size of modules & $1.97 \mathrm{~m} \times 0.99 \mathrm{~m}$ \\
Number of modules in Tehran & 20 \\
Number of modules in Banderabbas & 66 \\
Cell Type & Polycrystal Silicon \\
Active Area & $0.63 \mathrm{~m}^{2}$ \\
\hline \hline
\end{tabular}

\section{RESULTS AND DISCUSSION}

LCA and LCCA for a PV system is performed. From the perspective of the generated electricity, the results are compared with the average electricity use of grid-connected distribution network in a residential building in Tehran and Bandar Abbas. The monetary benefits of the generated electricity are calculated based on the tariff of the electricity 
costs in different months in Tehran and Bandar Abbas as moderate and hot climate cities respectively. Income is defined as monetary benefits of using PV system; i.e. the prices of an average electricity load which should be supplied by national electricity distribution network in the absence of the PV system, outcome is the initial investment and maintenance costs of the PV system. Cash flow means the sum of the income and the outcome, and the discounted cash flow is calculated from multiplying the cash flow with discounted rate.

TABle II: Calculation TABle of Payback Period Time, Monetary UNIT IS USD IN 2016 (AUTHORS)

\begin{tabular}{|c|c|c|c|c|}
\hline Year & 1 & 2 & 3 & $n$ \\
\hline Income & 60.12 & 60.12 & 60.12 & \\
\hline Outcome & 2515.80 & 25.158 & 25.158 & \\
\hline Cash flow & -2455.68 & 34.96 & 34.96 & \\
\hline Discounted cash flow & -368.35 & 5.24 & 5.24 & \\
\hline $\begin{array}{l}\text { Cumulative discounted cash } \\
\text { flow }\end{array}$ & -368.35 & -363.11 & -357.86 & \\
\hline
\end{tabular}

Table II presents the calculation of the first three years of the life span of the PV system in Tehran and continues until the Cumulative Cash Flow becomes zero. This parameter denotes the time in which system will produce the energy equal to the energy which is needed to produce the modules, as a compensation during the life cycle of the system.

The cumulative cash flow of the PV system in Tehran and Bandar Abbas shows that the payback period of PV systems are 71 years and 47 years, respectively. Our considerations in this evaluation is limited to the current tariffs of the electricity costs, governmental subsidies (which encompass half of the initial investment), maintenance costs (1\% of initial costs, annually) and the discount rate of $15 \%$. The maintenance costs in the whole life cycle of the PV system is a considerable amount and if we exclude the maintenance costs from our calculations, the payback period of the system will become 41 and 32. This maintenance costs include cleaning and repairing, but is not required regularly despite cleaning which should be on a regular basis [23] (which can be increase through the life time of the system). Life cycle cost analysis is a comprehensive approach which can include different factors and if we omit some of these factors, the result can change significantly, hence these results become irrational and unreliable [5]. However, there are some costs such as dismantling and disposal costs which due to a dearth of information is not possible. Based on some studies there is a declining trend for the costs of the manufacturing according to the improvement in the technologies around $4 \%$ per annum [24].

TABLE III: GLOBAL WARMING POTENTIAL PER MWH (AUTHORS)

\begin{tabular}{lccc}
\hline \hline Type & $\begin{array}{c}\text { Global warming potential per } \\
\text { 1MWh }\end{array}$ & $\begin{array}{c}\text { Global warming potential in } \\
\text { Tehran }\end{array}$ & $\begin{array}{c}\text { Global warming potential in } \\
\text { Bandarabbas }\end{array}$ \\
\hline Photovoltaic & $106[19]$ & 31.8 & 84.8 \\
Traditional Gas & $577[20]$ & 173.1 & 461.6 \\
Traditional Oil & $893[20]$ & 267.9 & Kg CO $\mathrm{Kg} \mathrm{CO}_{2}$ eq/ MW.h $\mathrm{MW}^{\mathrm{h}}$ \\
\hline \hline
\end{tabular}

To make a clear comparison between the environmental impacts based on BEES methods we have presented the normalized environmental impacts in Fig. 1 [18]. As it is clearly presented in Fig. 1, there is a considerable potential in global warming in comparison with other environmental impacts. Therefore, a comparison is carried out in order to evaluate the global warming potential of PV systems in comparison with other alternatives of electricity production systems which are commonly used in Iran. Fig. 1, shows that environmental impacts of using photovoltaic systems are considerably higher in Bnadarabbas compared to Tehran, this difference is attributed to significant dissimilarity in size and number of required photovoltaic panels. Since more photovoltaic panels are required in BandarAbbas, more environmental impacts are expected in this case. These environmental impacts caused by energy consumption and emission released in the production phase of photovoltaic panels. It is estimated that the manufacturing of photovoltaic panels has $81 \%$ of life cycle energy use, also the efficiency of photovoltaic panels is relatively low [23]. Therefore, using more efficient photovoltaic panels [25] and improving the technology of manufacturing of photovoltaic panels would lead to a considerable reduction in life cycle energy consumption and environmental impacts [5]. Also we have performed a comparative assessment of environmental impacts of different electricity industry alternatives which is presented in Table III and Fig. 2. It is evident that the PV system have the minimum global warming potential when it's compared with inefficient traditional systems. Table III and Fig. 2, clearly show the three scenarios of electricity generation. There is much higher global warming potential in traditional electricity generating systems which use oil and gas as major fuels in comparison with photovoltaic systems. As shown in Table III and Fig. 2.

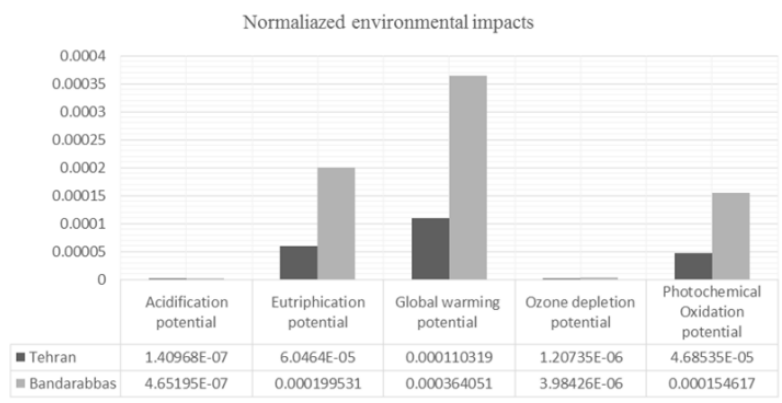

Fig. 1. Normalized environmental impact assessment (Authors).

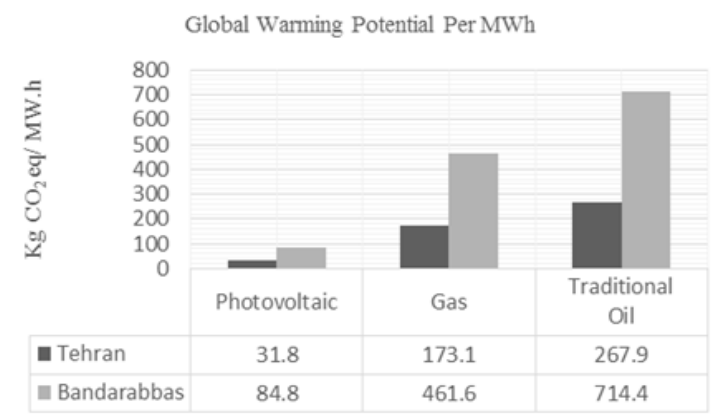

Fig. 2. Global Warming Potential Per MWh (Authors). 
Global warming potential in Tehran and BandarAbbas are 173.1 and $461.6 \mathrm{KgCo}_{2} \mathrm{eq} / \mathrm{MWh}$ respectively, for gas-based electricicty generating systems, and also 267.9 and 714.4 $\mathrm{KgCO}_{2} \mathrm{eq} / \mathrm{MWh}$ for oil-based electricty generating systems. While the global warming potential in Tehran and BandarAbbas will be decreased significantly to 31.8 and 84.8 $\mathrm{KgCO}_{2} \mathrm{eq} / \mathrm{MWh}$ if only photovoltaic systems are used as electricity generating systems. It shoud be noted again, that these results are presened for a single-house's electricity need Also the difference between Tehran and BandarAbbas in the global warming potential must be attributed to the differences of the average electricity consumption in these cities because of the conventional cooling and heating devices and climatic situation. Considering the on-site power generation of the PV systems, there is no transmission and distribution loss which will affect the results [23].

\section{CONCLUSION}

Impacts of the PV system in buildings are the most important results of this study. From the perspective of environmental concerns i.e. global warming potential, PV systems are effective alternatives in order to control and reduce environmental impacts of building sector. Comparing the results with the economic and environmental situation of Iran and improvements in the PV technology shows that from the economic perspective it is not practical to install the PV modules on the buildings with the current market prices, but by considering environmental issues like global warming potentials integrating the PV modules have more advantages than other current sources of energies. We made our assumptions based on the governmental subsidies to the tariffs of the electricity costs for the consumers; however, it is more wisely to increase the allotment of governmental subsidies to the renewable energy sector than electricity costs which are generated from non-renewable resources. In addition to the results, areas with high solar radiation (e.g. BandarAbbas) are good possible choices for the installation of solar systems [5], [6] and converting solar energy to electricity, although we should consider high temperatures as a negative factor for its conversion and efficiency [26], [27].

It also should be noted that cost definition should not be limited to direct financial issues, because environmental pollutant emissions which are released by using fossil fuels such as oil and gas in traditional electricity generating plants, have a considerable potential in negative environmental impacts. These negative impacts on environment result in climate change consequences and reduce the quality of life and increase the number of fatality in cities and eventually increase the financial burden on the government drastically.

This extra financial burden is the most paramount important problem for all of the developing countries including Iran. Also the uncertainty of financial security of fossil fuel based energy systems all around the world especially in Middle East should be considered as possible future costs.

Although there are little environmental impacts caused by using photovoltaic systems in comparison with using oil and gas in traditional electricity generating plants and this is a good reason for recommending photovoltaic systems, the economic analysis shows that financial problems are the main obstacle which limit widespread use of this technology in the developing countries. It shows that more governmental financial support should be considered for using photovoltaic systems, in order to encourage people for utilizing photovoltaic systems. This is obvious that this financial support will be recompensed by reducing the environmental costs in near future. However, large-scale exploitation of PV systems has some consequences which are not studied deeply yet such as recycling, non-hazardous gasses, dismantling, disposing, material depletions and transportation. Hence, these environmental externalities, and considering the growing effect of technologies besides the reducing costs can be further studied.

\section{REFERENCES}

[1] IEA, "Trends in photovoltaic applications: Survey report of selected IEA countries between 1992 and 2006," Report IEA-PVPS, 2010.

[2] Syndicat des énergies renouvelables (SER). SOLER. Etat des lieux du parc photovoltaïque français au 30 juin, 2010.

[3] E. A. Alsema et al., "Environmental impacts of PV electricity generation e a critical comparison of energy supply options," in Proc. 21st European Photovoltaic Solar Energy Conference, 2006.

[4] IEA, "Analysis of PV system's values beyond energy e by country and stakeholder," Report IEA-PVPS, 2008.

[5] J. Peng, L. Lu, and H. Yang, "Review on life cycle assessment of energy payback and greenhouse gas emission of solar photovoltaic systems," Renewable and Sustainable Energy Reviews, vol. 19, pp. 255-274, 2013.

[6] Y. Fu, X. Liu, and Z, Yuan, "Life-cycle assessment of multi-crystalline photovoltaic (PV) systems in China," Journal of Cleaner Production, vol. 86, pp. 180-190, 2015.

[7] L. Lu and H. X. Yang, "Environmental payback time analysis of a roof-mounted building-integrated photovoltaic (BIPV) system in Hong Kong," Applied Energy, vol. 87, pp. 3625-3631, 2013.

[8] M. A. Aguado-Monsonet, "The environmental impact of photovoltaic technology," Institute for Prospective Technological Studies Seville, Contract no JOR-CT95-0066, January 1998.

[9] A. Anctil and V. Fthenakis. (2012). Life cycle assessment of organic photovoltaics, third generation photovoltaics. [Online]. Available: http://www.intechopen.com/books/third-generation-photovoltaics/life -cycle-assessment-of-organicphotovoltaics

[10] N. Espinosa, R. Garci 'a-Valverde, A. Urbina, and F. C. Krebs, “A life cycle analysis of polymer solar cell modules prepared using roll-to-roll methods under ambient conditions," Solar Energy Materials \& Solar Cells, vol. 95, pp. 1293-1302, 2011.

[11] N. Kittner and H. Shabbir, "Gheewala and richard kamens. Life cycle considerations for monocrystalline photovoltaics in Thailand," Journal of Sustainable Energy \& Environment, vol. 3, pp. 143-146. 2013.

[12] M. Bravi, M. L. Parisi, E. Tiezzi, and R. Basosi, "Life cycle assessment of advanced technologies for photovoltaic panels' production," International Journal of Heat and Technology, 2010.

[13] M. Ito. Life cycle assessment of PV systems, crystalline silicon-properties and uses. Tokyo Institute of Technology, Japan. [Online]. Available from: http://www.intechopen.com/books/crystalline-silicon-properties-anduses/life-cycle-assessment-of-pv-systems

[14] R. Wilson and A. Young, "The embodied energy payback period of photovoltaic installations applied to buildings in the U.K," Building and Environment, vol. 31, no. 4, pp. 299-305, 1996.

[15] V. Baharwani, N. Meena, A. Dubey, U. Brighu, and J. Mathur, "Life cycle analysis of solar PV system: A review," International Journal of Environmental Research and Development, vol. 4, no. 2, pp. 183-190,, 2014

[16] M. M. Aman, K. H. Solangi et al., "A review of Safety, Health and Environmental (SHE) issues of solar energy system," Renewable and Sustainable Energy Reviews, vol. 41, pp. 1190-1204, 2015.

[17] A. Meijer, M. A. J. Huijbregts, J. J. Schermer, and L. Reijnders, "Life-cycle assessment of photovoltaic modules: Comparison of mc-Si, InGaP and $\mathrm{InGaP} / \mathrm{mc}-\mathrm{Si}$ solar module," Progress in photovoltaics: research and applications, vol. 11, pp. 275-287, 2003.

[18] B. C. Lippiatt, BEES 4.0 Building for Environmental and Economic Sustainability Technical Manual and User Guide, National Institute of Standards and Technology, 2007. 
[19] R. Reidy, M. Davis, R. Coony, S. Gould, C. Mann, and B. Sewak, Guidelines for Life Cycle Cost Analysis, Stanford University, Land and Buildings, 2005.

[20] K. P. Bhandari, J. M. Collier, Randy J. Ellingson, and D. S. Apul. "Energy payback time (EPBT) and energy return on energy invested (EROI) of solar photovoltaic systems: A systematic review and meta-analysis," Renewable and Sustainable Energy Reviews, vol. 47, pp. 133-141, 2015.

[21] R. A. Breakey, S. C. Myers, and F. Allen, Principles of Corporate Finance, Mc Grow Hill, 2010.

[22] Specialized Holding Companies. [Online]. Available: http://www.moe.gov.ir

[23] R. Kannan, K. C. Leong, R. Osman, H. K. Ho, and C. P. Tso, "Life cycle assessment study of solar PV systems: An example of a $2.7 \mathrm{~kW}$ distributed solar PV sysytems in Singapore," Solar Energy, vol. 80, pp. 555-563, 2006

[24] Power \& Energy Technology. [Online]. Available: http://www.solarbuzz.com

[25] A. F. Sherwani, and J. A. Usmani, "Life cycle assessment of solar PV based electricity generation systems: A review," Renewable and Sustainable Energy Reviews, vol. 14, no. 1, pp. 540-544, 2010.

[26] J. J. Wysocki and P. Rappaport, "Effect of temperature on photovoltaic solar energy conversion," Journal of Applied Physics, vol. 31, no. 3, pp 571-578, 1960.

[27] E. Skoplaki and J. A. Palyvos, "On the temperature dependence of photovoltaic module electrical performance: A review of efficiency/power correlations," Solar Energy, vol. 83, no. 5, pp. 614-624, 2009

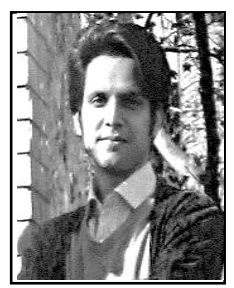

Hashem Amini Toosi is an MSc student in architecture and energy. He was born in Mashhad, Iran, on Feb 12, 1989. He has received bachelor of civil engineering from Ferdowsi University of Mashhad in 2013, master of architecture and energy from University of Tehran in 2016

He has been involved in various research projects at Ferdowsi university of Mashhad and Shahid Beheshti university of Tehran related to architectural technologies and energy saving strategies of buildings. Also he has published many research papers related to architecture and civil engineering in scientific journals and international conferences and was elected as the best researcher at Ferdowsi university of Mashhad in 2011. He presented a comprehensive LCA method in an architectural design process in his master dissertation "A guide to building life cycle assessment in architectural design process" at University of Tehran in 2016 and he has focused on different aspects of building life cycle assessment in his research from 2013 till now. Besides his academic works, he has experiences in working with renovation organization of Tehran municipality from 2014 to 2016.

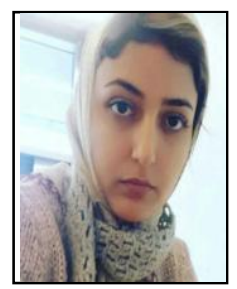

Zahra Balador is a PhD student of architecture, born in Tehran, on Feb 26, 1987. She has received bachelor of architectural engineering from Ferdowsi University of Mashhad in 2010, Master of Energy and Architecture from University of Tehran in 2015.

She has been an editor of the Energy section in the Journal of Technology in Architecture \& Construction Management, Scientific Association of Shahid
Beheshti University. She passed the internship at UN-Habitat, United Nations Human Settlements Program, office of Tehran, Iran in 2015. Also she has been the Energy consultant (acoustic) and designer at University of Tehran Civil and Architecture Home, lecturer of building energy analysis soft wares in the Academy of Architecture Institute in 2015, researcher at Office of Sustainability of Amirkabir University, Head of the energy community in the Institute of young architects and urban designers, lecturer of undergraduate courses, University of Applied Science and Technology, Tehran from 2014 to 2015.

Besides, she has working experience in architectural companies. She published papers and works include papers in International Journal of Engineering and Technology, Advanced Materials Research, and proceedings of different international conferences, and translation of a book "Light Structure and Structure of Light", by Horst Berger. Most of the works are in the field of sustainable architecture which is the author's research interest.

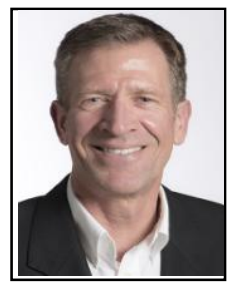

Morten Gjerde is an Assoc. Arts in architecture. He is a fellow member of New Zealand Institute of Architects, New Zealand Registered Architect, California (USA) Registered Architect, NCARB Certification. Also he has been a member of the Faculty Academic Committee since 2009. He was a director of Landscape Architecture Programme at Victoria University from 2011 to 2012. His recent publications are in buildings, architectural science review, and international journal of constructed environment.

Dr. Morten Gjerde maintains interest in professional practice through Morten Gjerde Architect Ltd, which has NZIA Practice status. The work of the practice is mainly in the field of urban design and all projects have a close connection with my academic and research agendas.

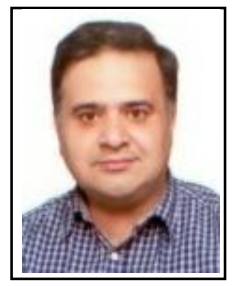

Ali Vakili-Ardebili is an assistant professor at University of Tehran. Dr. Ali Vakili-Ardebili has obtained his $\mathrm{PhD}$ in architecture from University of Liverpool in United Kingdom in 2006.

$\mathrm{He}$ is a consultant and researcher in sustainable building design and architecture. He has been teaching at University of Liverpool in the United Kingdom, University of Toronto and Ryerson University in Canada and University of Tehran in Iran. $\mathrm{He}$ is an academic member (assistant professor) of School of Architecture at University of Tehran and many research projects are being carried out under his supervision. Also he has published many papers in scientific journals and international conferences and authored two books. 